\title{
Dampak Covid-19 Terhadap Pembelajaran Online di Sekolah Menengah Pertama Kota Semarang
}

\author{
The Effects of Covid-19 towards Online Learning on Junior \\ High School in Semarang
}

\author{
Indri Murniawaty ${ }^{1}$, Dwi Puji Astuti ${ }^{2}$, Ahmad Sehabuddin ${ }^{3}$, Devi Cahyaningrum ${ }^{4}$ \\ 1,2,3,4 Jurusan Pendidkan Ekonomi, Universitas Negeri Semarang
}

\begin{tabular}{l} 
ARTICLE INFO \\
\hline Article history: \\
DOI: \\
10.30595/pssh.v1i.71 \\
Submitted: \\
April 12, 2021 \\
Accepted: \\
June 10, 2021 \\
Published: \\
June 14, 2021 \\
\hline
\end{tabular}

Keywords:

COVID-19, Junior high school, Online learning

\begin{abstract}
Efforts to prevent the spread of the COVID-19 virus implemented in Indonesia in the education sector have resulted in learning at junior high schools in Semarang City using online learning through parental guidance. This study aims to describe the impact of COVID-19 on online learning in Semarang City's first schools. Online learning can use digital technology such as google classrooms, study houses, zoom, video conferencing, telephone or live chat and others. This research is a qualitative research. The informants in this study were students, teachers and parents of junior high school guardians in Semarang City. The results of this study were (1) The impact felt by students on the teaching and learning process at home was that students felt they had more experience than learning in class. (2) From the parent guardian's point of view, the impact felt is the additional cost of purchasing internet quota and parents have to spend time accompanying their children in online learning. (3) The impact felt by the teacher is that not all are proficient in using internet technology or social media as a learning tools.
\end{abstract}

This work is licensed under a Creative Commons Attribution 4.0 International License.

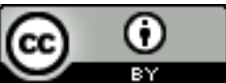

\section{Corresponding Author:}

Devi Cahyaningrum

Jurusan Pendidikan Ekonomi,

Fakultas Ekonomi, Universitas Negeri Semarang

Jalan Kampus Timur, Sekaran, Gunungpati, Kota Semarang, Jawa Tengah, Indonesia

Email: cahyaningrumdevi@gmail.com

\section{PENDAHULUAN}

Saat ini dunia sedang berduka karena maraknya wabah coronavirus. Coronavirus Diseases 2019 (COVID19) adalah penyakit jenis baru yang belum pernah diidentifikasi sebelumnya pada manusia. Pada tanggal 30 Januari 2020 WHO telah menetapkan sebagai kedaruratan kesehatan masyarakat yang meresahkan dunia. Pada tanggal 2 Maret 2020, Indonesia melaporkan kasus konfirmasi COVID-19 sebanyak 2 kasus. Sampai dengan tanggal 16 Maret 2020 ada 10 orang yang dinyatakan positif corona [1].

Virus COVID-19 memiliki dampak yang luar biasa bagi masyarakat di Indonesia saat ini. Berdasaran informasi dari kompas, 28/03/2020 dampak virus COVID-19 terjadi diberbagai bidang seperti sosial, ekonomi, pariwisata dan pendidikan. Surat Edaran (SE) yang dikeluarkan pemerintah pada 18 Maret 2020, menjelaskan segala kegiatan didalam dan diluar ruangan di semua sektor sementara waktu ditunda demi mengurangi penyebaran corona terutama pada bidang pendidikan. Pada tanggal 24 Maret 2020 Menteri Pendidikan dan Kebudayaan Republik Indonesia mengeluarkan Surat Edaran Nomor 4 Tahun 2020 Tentang Pelaksanaan Kebijakan Pendidikan Dalam Masa Darurat Penyebaran COVID, dalam Surat Edaran tersebut dijelaskan bahwa proses belajar dilaksanakan di rumah 
melalui pembelajaran daring/jarak jauh dilaksanakan untuk memberikan pengalaman belajar yang bermakna bagi siswa. Belajar di rumah dapat difokuskan pada pendidikan kecakapan hidup antara lain mengenai pandemi Covid-19.

Saat ini di Indonesia, beberapa kampus dan sekolah mulai menerapkan kebijakan kegiatan belajar mengajar dari jarak jauh atau kuliah online. Semua orang lantas mengambil jarak demi memutus rantai penularan COVID-19. Tempat-tempat ibadah kini mulai sepi, agenda-agenda massa dihilangkan, karena COVID-19 pula istilah "Work From Home" (WFH) jadi melejit COVID-19 juga memberikan dampak serius di sektor pendidikan, baik di Indonesia maupun secara global. pemerintah mengumumkan Ujian Nasional (UN) di tahun ini resmi ditiadakan. Mulai dari tingkat Sekolah Dasar (SD) hingga setingkat Sekolah Menengah Atas (SMA). Pemerintah telah meniadakan Ujian Nasional (UN) untuk tahun 2020. Tenaga dan peserta didik di seluruh dunia merasakan betul dampak yang luar biasa dari wabah virus corona yang pertama kali muncul di China.

Korban akibat wabah COVID-19, tidak hanya pendidikan di tingkat Sekolah Dasar/Madrasah Ibtidaiyah, Sekolah Menengah Pertama/Madrasah Stanawiyah, dan Sekolah Menengah Atas/Madrasah Aliyah, tetapi juga perguruan tinggi. Seluruh jenjang pendidikan dari sekolah dasar/ibtidaiyah sampai perguruan tinggi (universitas) baik yang berada dibawah Kementerian Pendidikan dan Kebudayaan RI maupun yang berada dibawah Kementerian Agama RI semuanya memperoleh dampak negatif karena pelajar, siswa dan mahasiswa "dipaksa" belajar dari rumah karena pembelajaran tatap muka ditiadakan untuk mencegah penularan COVID-19. Padahal tidak semua pelajar, siswa dan mahasiswa terbiasa belajar melalui Online. Apalagi guru dan dosen masih banyak belum mahir mengajar dengan menggunakan teknologi internet atau media sosial terutama di berbagai daerah.

Pembelajaran yang dilaksanakan pada sekolah menengah pertama di Kota Semarang juga menggunakan pembelajaran daring atau biasa dikenal dengan e-learning melalui bimbingan orang tua. E-learning sebagai penyampaian program pembelajaran, pelatihan, atau pendidikan dengan menggunakan sarana elektronik seperti komputer atau alat elektronik lain seperti telepon genggam dengan berbagai cara untuk memberikan pelatihan, pendidikan, atau bahan ajar [2]. E-learning memungkinkan peserta didik untuk belajar memahami komputer di tempat masing-masing tanpa harus secara fisik bertemu face to face di kelas dengan gurunya.

Tujuan dari penelitian ini adalah untuk mendapatkan informasi mengenai dampak dan kendala dari pandemik COVID-19 terhadap kegiatan belajar mengajar di Sekolah Menengah Pertama di Kota Semarang dan menggunakan metode kualitatif.

\section{METODE PENELITIAN}

Penelitian menggunakan metode studi kasus eksplorasi dan pendekatan penelitiannya menggunakan metode studi kasus kualitatif yang digunakan untuk mendapatkan informasi kendala dan akibat dari pandemik COVID-19 terhadap kegiatan proses belajar mengajar di sekolah menengah pertama. Ukuran sampel didasarkan pada pencapaian kedalaman dan kekayaan deskripsi. Ukuran sampel bukan masalah opini representatif dan pandangan, tetapi lebih merupakan masalah kekayaan informasi [3]. Wawancara semi-terstruktur dilakukan dan daftar pertanyaan disusun untuk wawancara dikembangkan berdasarkan literatur terkait. Responden untuk penelitian ini adalah guru, siswa dan orang tua murid di sekolah menengah pertama di Kota Semarang.

Penelitian ini adalah studi kasus eksplorasi dan sampel dipilih menggunakan metode purposive sampling. Dalam penelitian kualitatif, teknik purposive sampling adalah metode yang digunakan untuk mencapai tujuan penelitian tertentu. Tidak ada batasan jumlah responden untuk membuat sampel purposive, asalkan informasi yang diinginkan dapat diperoleh dan dihasilkan.

\section{HASIL DAN PEMBAHASAN}

Penyebaran virus corona ini pada awalnya sangat berdampak pada dunia ekonomi yang mulai lesu, tetapi kini dampaknya dirasakan juga oleh dunia pendidikan. Kebijakan yang diambil oleh banyak negara termasuk Indonesia dengan meliburkan seluruh aktivitas pendidikan, membuat pemerintah dan lembaga terkait harus menghadirkan alternatif proses pendidikan bagi peserta didik maupun mahasiswa yang tidak bisa melaksanakan proses pendidikan pada lembaga pendidikan.

Dengan munculnya pandemik COVID-19 kegiatan belajar mengajar yang semula dilaksanakan di sekolah kini menjadi belajar di rumah melalui daring. Pembelajaran daring dilakukan dengan disesuaikan kemampuan masingmaisng sekolah. Belajar daring (online) dapat menggunakan teknologi digital seperti google classroom, rumah belajar, zoom, video conference, telepon atau live chat dan lainnya. Namun yang pasti harus dilakukan adalah pemberian tugas melalui pemantauan pendampingan oleh guru melalui whatsapp grup sehingga anak betul-betul belajar. Kemudian guru-guru juga bekerja dari rumah dengan berkoordinasi dengan orang tua, bisa melalui video call maupun foto kegiatan belajar anak dirumah untuk memastikan adanya interaksi antara guru dengan orang tua.

Belajar dirumah tidak menjadi masalah karena pembelajaran bisa dilakukan kapan dan dimana saja, apalagi sudah ada didukung dengan sistem daring [4]. Jadi proses pembelajaran bisa terjadi di rumah, di sekolah maupun di 
masyarakat. Oleh karena itu semua bisa berjalan dengan baik, dengan dukungan fasilitas seperti internet. Berikut ini dampak yang terjadi dengan adanya pembelajaran daring:

\section{Dampak Terhadap Murid}

Dampak yang dirasakan murid pada proses belajar mengajar di rumah adalah para murid merasa memiliki pengalaman lebih banyak di bandingkan dengan pembelajaran di kelas. Namun, disisi lain ada kendala yang dihadapi murid, yaitu belum ada budaya belajar jarak jauh karena selama ini sistem belajar dilaksanakan melalui tatap muka, murid terbiasa berada di sekolah untuk berinteraksi dengan temantemannya, bermain dan bercanda gurau dengan teman-temannya serta bertatap muka dengan para gurunya, dengan adanya metode pembelajaran jarah jauh membuat para murid perlu waktu untuk beradaptasi dan mereka menghadapi perubahan baru yang secara tidak langsung akan mempengaruhi daya serap belajar mereka.

Dampak selanjutnya yang dialami murid yaitu sekolah diliburkan terlalu lama membuat anak-anak jenuh, anak-anak mulai jenuh di rumah dan ingin segera ke sekolah bermain dengan teman-temannya, murid terbiasa berada di sekolah untuk berinteraksi dengan teman-temannya, bermain dan bercanda gurau dengan teman-temannya serta bertatap muka dengan para gurunya. Murid merasa kehilangan jiwa sosialnya karena jika di sekolah mereka bisa bermain berinteraksi dengan teman-temnanya tetapi kali ini mereka tidak bisa dan hanya sendiri di rumah bersama orang tua, interaksi dengan sesame teman, guru dan orang-orang disekolah akan menjadi berkurang. Adanya wabah COVID-19 memaksa para murid harus menggunakan teknologi, sehingga suka tidak suka dan mau tidak mau harus belajar dan siap mengajar melalui jarak jauh dengan menggunakan teknologi.

Jika seorang siswa tertentu belajar terbaik dengan cara tertentu, ia harus dihadapkan pada berbagai pengalaman belajar untuk menjadi pembelajar online yang lebih fleksibel [5]. Siswa dengan sistem online lebih cenderung memiliki gaya belajar visual dan baca tulis yang lebih kuat [6]. Neurotisme dan keterbukaan terhadap pengalaman mempengaruhi niat siswa untuk mengadopsi pembelajaran online melalui lima nilai yang dirasakan dari pembelajaran online [7]. Khususnya, siswa yang terbuka untuk pengalaman lebih memperhatikan kualitas pembelajaran online. Siswa yang lebih neurotis menghindari stres karena belajar dalam situasi yang tidak mereka kenal. Selain itu, siswa cenderung mengadopsi pembelajaran online ketika mereka merasa pembelajaran online memenuhi kebutuhan emosional dan sosial mereka.

Kebutuhan belajar siswa dan lingkungan belajar online adalah sejalan [8]. Adanya pembelajaran online membuat mereka merasa bosan. Setiap siswa memiliki kemampuan menangkap yang berbeda-beda dengan adanya pembelajaran online ini. Kemandirian sangat di tuntut dalam keberhasilan dari belajar online ini.

\section{Dampak Terhadap Orang Tua}

Kendala yang dihadapi para orang tua adalah adanya penambahan biaya pembelian kuota internet bertambah, teknologi online memerlukan koneksi jaringan. Untuk melakukan permbelajaran online selama beberapa bulan tentunya akan diperlukan kuota yang lebih banyak lagi dan secara otomatis akan meningkatkan biaya pembelian kuota internet. Kendala selanjutnya yang dirasakan orang tua yaitu mereka harus meluangkan lebih ekstra waktu kepada anak anak mendampingi belajar online, mereka harus membagi waktu lagi untuk mendampingi anak-anaknya dalam belajar online, yang tentunya akan berpengaruh pada aktivitas pekerjaan rutin sehari-hari yang akan menjadi berkurang tidak jarang para orang tua juga ikut belajar bersama anak-anaknya dan ikut membantu mengerjakan tugas bersama-anak anaknya.

Pembelajaran online juga memaksa para orang tua harus melek teknologi, sehingga suka tidak suka dan mau tidak mau harus belajar dan siap mengajar melalui jarak jauh dengan menggunakan teknologi. Orang tua harus menyiapkan alat dan sistem pembelajaran jarak jauh dan melakukan bimbingan kepada anak-anak agar bisa menggunakan teknologi modern dalam pembelajaran untuk meningkatkan kualitas anaknya. Orang tua yang mempunyai kendala dengan tuntutan kerjanya dan tuntutan untuk mendampingi pembelajaran anak di rumah. Meskipun demikian, banyak juga orang tua peserta didik yang sangat apresiatif karena mengalami sendiri bahwa mengajar anak-anak di rumah saja sulit, apalagi seperti guru yang harus mengajar banyak anak di kelas. Adanya kesenjangan antara ideal dan kenyataan dalam mengintegrasikan interaksi sebagai bagian dari aktivitas online dalam pembelajaran [9].

\section{Dampak Terhadap Guru}


Dampak yang dirasakan guru yaitu tidak semua mahir menggunakan teknologi internet atau media sosial sebagai sarana pembelajaran. Beberapa guru belum sepenuhnya mampu menggunakan perangkat atau fasilitas untuk penunjang kegiatan pembelajaran online dan perlu pendampingan dan pelatihan terlebih dahulu. Kompetensi guru dalam menggunakan teknologi akan mempengaruhi kualitas program belajar mengajar oleh karena itu sebelum diadakan program belajar online para guru wajib untuk diberikan pelatihan terlebih dahulu. Kendala yang dialami guru, yaitu para guru belum ada budaya belajar jarak jauh karena selama ini sistem belajar dilaksanakan adalah melalui tatap muka, para guru terbiasa berada di sekolah untuk berinteraksi dengan murid-murid, dengan adanya metode pembelajaran jarah jauh membuat para guru perlu waktu untuk beradaptasi dan mereka menghadapi perubahan baru yang secara tidak langsung akan mempengaruhi kualitas hasil belajar.

Dampak selanjutnya yang dialami guru yaitu sekolah diliburkan terlalu lama membuat para guru jenuh, guru terbiasa berada di sekolah untuk berinteraksi dengan teman-temannya. Kemudian guru juga akan kehilangan jiwa sosial, jika di sekolah mereka bisa bermain berinteraksi dnegan guru-guru lain dan para murid tetapi kali ini mereka belum terbiasa. Adanya wabah Covid-19 memaksa para guru harus menggunakan teknologi, sehingga suka tidak suka dan mau tidak mau harus belajar dan siap mengajar melalui jarak jauh dengan menggunakan teknologi. Setiap sekolah menyiapkan alat dan sistem pembelajaran jarak jauh dan melakukan bimbingan teknis kepada para guru agar bisa menggunakan teknologi modern dalam pembelajaran untuk meningkatkan kualitas anak didik di sekolah. Kendala lain yang dihadapi para guru adalah adanya penambahan biaya pembelian kuota internet. Kompetensi guru dalam memanfaatkan teknologi dan menguasai teknologi untuk pembelajaran dituntut untuk meningkat dengan cepat untuk merespon Online Home Learning. Komunikasi guru dan sekolah dengan orang tua harus terjalin dengan lancar. Jam kerja juga menjadi tidak terbatas karena harus berkomunikasi dan berkoordinasi dengan peserta didik, orang tua, guru lain, dan kepala sekolah. Tidak setiap guru cepat mengadopsi dan belajar teknoloogi, bahkan waktu kerja mereka pun menjadi tidak terbatas.

Ada banyak penelitian tentang implementasi teknologi dalam pendidikan online berkaitan dengan penghematan biaya dan efisiensi, bahwa peningkatan kualitas dan efektivitas pendidikan online memerlukan kerangka kerja yang harus diterapkan di sekolah [10]. Kerangka yang diusulkan memberikan panduan praktis kepada para pemangku kepentingan dalam penilaian kualitas pengajaran dan pembelajaran online. Beberapa faktor yang dapat menciptakan pengalaman belajar yang menarik bagi pembelajar online [11]. Faktor utama antara lain sebagai berikut: menciptakan dan memelihara lingkungan belajar yang positif, membangun komunitas belajar, memberikan umpan balik yang konsisten secara tepat waktu, dan menggunakan teknologi yang tepat untuk mengirimkan konten yang tepat. Seiring meningkatnya peluang pembelajaran online dalam masyarakat saat ini, guru perlu mempertimbangkan cara-cara tambahan untuk merancang instruksi online secara efektif [12]. Mengembangkan strategi yang diperlukan untuk pembelajaran online dengan sukses membutuhkan pemahaman tentang gaya belajar. Seperti halnya di kelas tatap muka, penggunaan gaya mengajar tertentu atau serangkaian gaya harus diperluas untuk mengatasi gaya belajar yang berbeda saat mengajar online. Pengajaran dan pembelajaran yang sukses tergantung pada semua peserta yang memiliki sikap yang diperlukan untuk berhasil di lingkungan online. Makalah ini memberikan informasi tentang gaya belajar dan mengajar, dan membahas bagaimana mengajar dengan berbagai gaya belajar dapat dilakukan dengan menggunakan alat dan sumber daya online yang tersedia.

\section{SOLUSI DAN SARAN}

Solusi bagi para siswa yakni siswa dan guru lebih interaktif dalam menggunakan aplikasi pembelajaran online, sehingga siswa tidak akan merasakan kejenuhan dalm pembelajaran. Solusi pembelajaran online bagi para guru supaya pembelajaran online berjalan dengan lancar yakni workshop atau pelatihan bagi para guru tentang pengembangan pembelajaran berbasis teknologi. Pelatihan dapat dilakukan secara daring dan konfrehensif. Solusi bagi orang tua, orang tua seyognyanya mendampingi anaknya dalam pembelajaran online. Untuk penelitian selanjutnya, tim peneliti merekomendasikan untuk melakukan penelitian tentang strategi dalam mengatasi kendala pembelajaran online pada masa pandemi covid-19.

\section{KESIMPULAN}

Dampak yang dirasakan murid pada proses belajar mengajar di rumah adalah para murid merasa memiliki pengalaman lebih banyak di bandingkan dengan pembelajaran di kelas namun kendala yang dirasakan oleh siswa yakni merasa jenuh dan belum terbiasa dengan pembelajaran online. Dari sisi orang tua wali, dampak yang dirasakan yakni adanya penambahan biaya pembelian kuota internet bertambah, teknologi online memerlukan koneksi jaringan 
dan orang tua harus meluangkan waktu untuk mendampingi anaknya dalam pembelajaran online. Sedangkan dampak yang dirasakan guru yaitu tidak semua mahir menggunakan teknologi internet atau media sosial sebagai sarana pembelajaran. Beberapa guru belum sepenuhnya mampu menggunakan perangkat atau fasilitas untuk penunjang kegiatan pembelajaran online dan perlu pendampingan dan pelatihan terlebih dahulu.

\section{Ucapan Terima Kasih}

Kami mengucapkan terima kasih kepada siswa, guru dan orang tua wali sekolah menengah pertama Kota Semarang yang telah meluangkan waktunya untuk memberikan informasi demi kelancaran penelitian ini. Kami juga beterima kasih banyak kepada tim redaksi penerbit artikel yang telah memfasiltasi sampai terbitnya atikel yang telah kami susun.

\section{DAFTAR PUSTAKA}

[1] Yurianto, Ahmad, Bambang Wibowo, K. P. 2020. Pedoman Pencegahan Dan Pengendalian Coronavirus Disease (COVID-19) (M. I. Listiana Azizah, Adistikah Aqmarina (ed.)).

[2] Prawiradilaga, D., S. 2013. Mozaik Teknologi Pendidikan E-learning. Jakarta: Prenadamedia Group.

[3] Guetterman, T. C. 2015. Descriptions of Sampling Practices within Five Approaches to Qualitative Research in Education and the Health Sciences.

[4] Suryawan, O. 2020. Guru Diminta Aktif Awasi Pembelajaran Daring Agar Siswa Tetap Fokus. BBALIPUSPANEWS.COM.

[5] Zapalska, A \& Brozik, D. 2006. Learning Styles and Online Education. Campus-Wide Information Systems, Vol. 23 No. 5, pp. 325-335. https://doi.org/10.1108/10650740610714080.

[6] Drago, W \& Wagner, R. 2004. Vark Preferred Learning Styles and Online Education. Management Research News, Vol. 27 No. 7, pp. 1 13. https://doi.org/10.1108/01409170410784211

[7] Watjatrakul, B. 2016. Online Learning Adoption: Effects of Neuroticism, Openness to Experience, and Perceived Values. Interactive Technology and Smart Education, Vol. 13 No. 3, pp. 229-243. https://doi.org/10.1108/ITSE-06- 2016-0017.

[8] Butler, K., C. 2012. A model of successful adaptation to online learning for college bound Native American high school students. Multicultural Education \& Technology Journal, Vol. 6 No. 2, pp. 60-76. https://doi.org/10.1108/17504971211236245.

[9] Yoo, S., Jeong Kim, H \& Young, K., S. (2014). Between ideal and reality: A different view on online-learning interaction in a crossnational context. Journal for Multicultural Education, Vol. 8 No. 1, pp. 13-30. https://doi.org/10.1108/JME-04-2013-0018

[10] Zhao, F. (2003). Enhancing the quality of online higher education through measurement. Quality Assurance in Education, Vol. 11 No. 4, pp. 214-221. https://doi.org/10.1108/09684880310501395.

[11] Chakraborty, M. \& Muyia, N., F. (2014). Strengthening student engagement: what do students want in online courses?". European Journal of Training and Development, Vol. 38 No. 9, pp. 782-802. https://doi.org/10.1108/EJTD-11-2013-0123.

[12] Lewis, S., Whiteside, A. \& Dikkers, A. (2015). Providing Chances for Students to Recover Credit: Is Online Learning a Solution?", Exploring Pedagogies for Diverse Learners Online (Advances in Research on Teaching, Vol. 25). Emerald Group Publishing Limited, pp 143-157. https://doi.org/10.1108/S1479368720150000027007. 